\title{
First example of diglycolamide-grafted resins: synthesis, characterization, and actinide uptake studies
}

\author{
Prasanta K. Mohapatra, ${ }^{\text {*a }}$ Seraj A. Ansari, ${ }^{a}$ Mudassir lqbal, ${ }^{\mathrm{b}}$ Jurriaan Huskens ${ }^{\mathrm{b}}$ \\ and Willem Verboom ${ }^{b}$
}

Two diglycolamide (DGA)-functionalized chelating extraction resins were prepared for the first time by grafting onto a silica matrix and were evaluated for their actinide ion uptake behavior. The resins with one and two DGA moieties, termed as resin-I and resin-II, were quite efficient for the actinide ions, particularly the tri- and the tetravalent ions in a way similar to the diglycolamide extractants. The hexavalent $\mathrm{UO}_{2}{ }^{2+}$ ion was poorly sorbed onto the resins. The resins were characterized by thermal analysis, while the surface area and surface morphology were analyzed by BET and SEM techniques. Resin-II showed a pre-concentration factor of $>100$ for Am(III) by elution with 0.01 M EDTA.

Received 28th June 2013

Accepted 31st January 2014

DOI: $10.1039 / \mathrm{c} 3 \mathrm{ra} 43280 \mathrm{~g}$

www.rsc.org/advances
Though solvent extraction-based separation methods have been used for actinide ion extraction in many radioactive waste remediation related activities, concern for the environment makes one imperative to explore other separation techniques, which are based on low inventory of volatile organic compounds (VOCs). Out of such techniques, solid phase extraction (SPE) has emerged as an excellent separation technique in view of a variety of factors such as low solvent inventory, easy phase sorption and elution, low physical degradation, minimum release of toxic organic solvents, and recycling options. ${ }^{12,13}$

Solid phase extractants can be of the type where the extractant in a suitable solvent is impregnated in the pores of a solid support. These SPEs have the advantages of both solvent extraction and ion-exchange based separation methods and can effect selective separations in column mode operations. However, though the solvent inventory is low as compared to solvent extraction-based separation methods, repeated use may give rise to a significant loss of the impregnated organic extractant from the pores by leaching. This can be limited by chemically grafting the resin with suitable ligating groups. Actinide ion sorption studies using grafted solid phase extraction resins have been reported by several groups. Though TODGA is generally known to be the most efficient extractant for trivalent actinides, its use as extraction chromatographic resin material is limited. ${ }^{\mathbf{1 4}, 15}$ There are several reports by Kumagai et al. $^{\mathbf{1 6 - 1 8}}$ who have prepared TODGA-based resins bound to polymer-immobilized silica particles. To our knowledge, the use of diglycolamide (DGA)-grafted solid phase extractants is unprecedented.

Herein, we report the first time synthesis and characterization of two DGA-grafted resin materials (Fig. 1), in addition to actinide ion uptake studies under acidic feed conditions. A comparative evaluation of these grafted resin materials is made 


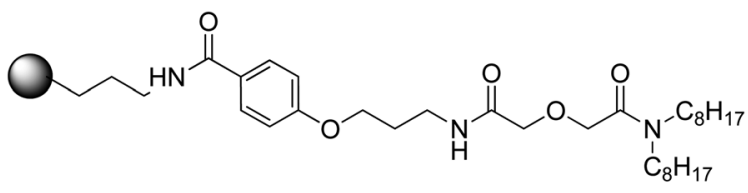

Resin-I

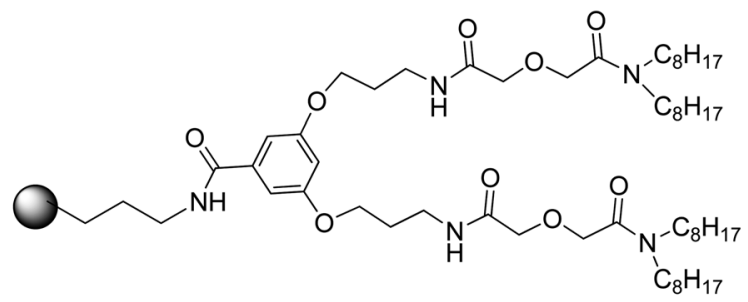

Resin-II

Fig. 1 Structures of the DGA-functionalized resins.

with the analogous TODGA-impregnated extraction chromatographic resin material.

\section{Experimental}

\subsection{Materials}

All reagents used in the present studies were of AR grade. Suprapur $\mathrm{HNO}_{3}$ (Merck) was used for preparing the aqueous feed solutions using Milli-Q water. Freshly obtained 2-thenoyltrifluroacetone (TTA, Fluka) was used along with HPLC grade xylene for preparing the $\mathrm{Pu}(\mathrm{Iv})$ extracts (vide infra).

\subsubsection{Synthesis of DGA-functionalized resins}

General. All moisture-sensitive reactions were carried out under an argon atmosphere. The solvents and all reagents were obtained from commercial sources and used without further purification. Compounds 1 (ref. 19) and 2 (ref. 20) were prepared according to literature procedures. Solvents were dried according to standard procedures and stored over molecular sieves. ${ }^{1} \mathrm{H}$ NMR and ${ }^{13} \mathrm{C}$ NMR spectra were recorded on a BRUKER (400 MHz) spectrometer. ${ }^{1} \mathrm{H}$ NMR $(400 \mathrm{MHz})$ and ${ }^{13} \mathrm{C}$ NMR $(100 \mathrm{MHz})$ chemical shift values are reported as $\delta$ using the residual solvent signal as an internal standard. All NMR measurements are recorded in $\mathrm{CDCl}_{3}$. Electrospray ionization (positive mode) mass spectra and high resolution mass spectra were recorded on a WATERS LCT mass spectrometer. Analytical TLC was performed using Merck prepared plates (silica gel 60 F-254 on aluminium). Column chromatography was carried out with Merck silica gel 60 (230-400 mesh).

Synthesis of ethyl p-DGA-benzoate (3). A mixture of $N, N^{\prime}$-dioctyldiglycolamic acid (1) $(5.50 \mathrm{~g}, 15.4 \mathrm{mmol})$, and ethyl 4-aminopropoxybenzoate (2) (3.43 g, $15.4 \mathrm{mmol})$, triethylamine $(1.81 \mathrm{~g}, 18.0 \mathrm{mmol})$, DCC $(3.30 \mathrm{~g}, 16.0 \mathrm{mmol})$, and HOBT ( $2.16 \mathrm{~g}$, $16.0 \mathrm{mmol})$ in chloroform $(200 \mathrm{~mL})$ was stirred for 2 days at room temperature. The solvent was evaporated and the resulting solid dissolved in $n$-hexane $(150 \mathrm{~mL})$. After filtration the solvent was evaporated under reduced pressure. The residue was purified by column chromatography $\left(\mathrm{SiO}_{2}, \mathrm{CH}_{2} \mathrm{Cl}_{2}-\mathrm{MeOH}\right.$ $=98: 2)$ to afford $3(6.84 \mathrm{~g}, 79 \%)$ as an oil. ${ }^{1} \mathrm{H}$ NMR: $\delta$
0.84-0.95 (6H, m, $\left.\mathrm{CH}_{3}\right), 1.19-1.34\left(20 \mathrm{H}, \mathrm{m}, \mathrm{CH}_{3}\left(\mathrm{CH}_{2}\right)_{5}\right), 1.40$ $\left(3 \mathrm{H}, \mathrm{t}, J=7.2 \mathrm{~Hz}, \mathrm{OCH}_{2} \mathrm{CH}_{3}\right), 1.46-1.59\left(4 \mathrm{H}, \mathrm{m}, \mathrm{NCH}_{2} \mathrm{CH}_{2}\right), 2.09$ $\left(2 \mathrm{H}\right.$, pentet, $\left.J=6.4 \mathrm{~Hz}, \mathrm{OCH}_{2} \mathrm{CH}_{2}\right), 3.09,3.30(2 \mathrm{H}, \mathrm{t}, J=7.5 \mathrm{~Hz}$, $\left.\mathrm{NCH}_{2}\right), 3.53\left(2 \mathrm{H}, \mathrm{q}, J=6.4 \mathrm{~Hz}, \mathrm{NHCH}_{2}\right), 4.12(2 \mathrm{H}, \mathrm{t}, J=6.4 \mathrm{~Hz}$, $\left.\mathrm{OCH}_{2}\right), 4.10,4.25\left(2 \mathrm{H}, \mathrm{s}, \mathrm{OCH}_{2}\right), 4.36(2 \mathrm{H}, \mathrm{q}, J=7.2 \mathrm{~Hz}, \mathrm{C}(\mathrm{O})$ $\left.\mathrm{OCH}_{2}\right), 6.93,7.99(2 \mathrm{H}, \mathrm{d}, J=8.8 \mathrm{~Hz}, \mathrm{ArH}), 8.05-8.15(1 \mathrm{H}, \mathrm{m}$, $\mathrm{NH}) .{ }^{13} \mathrm{C}$ NMR: $\delta 14.2,20.7,22.6,26.8,27.5,28.2,28.8,29.1$, 31.8, 36.2, 46.3, 46.9, 60.4, 65.8, 69.5, 71.7, 113.7, 122.1, 132.1, 163.13, 168.5, 170.4, 175.6. HRMS: calculated 563.7889 for $\mathrm{C}_{32} \mathrm{H}_{55} \mathrm{~N}_{2} \mathrm{O}_{6}$; found: 563.7823, $[\mathrm{M}+\mathrm{H}]^{+}$.

Synthesis of p-DGA-benzoic acid (4). To a solution of ester 3 $(5.00 \mathrm{~g}, 8.9 \mathrm{mmol})$ in a mixture of THF-methanol $=6: 1(70 \mathrm{~mL})$ was slowly added $\mathrm{NaOH}(0.42 \mathrm{~g}, 10.6 \mathrm{mmol})$ at $0{ }^{\circ} \mathrm{C}$. The mixture was allowed to come to room temperature and was stirred overnight. The solvent was evaporated under reduced pressure. The residue was dissolved in ethyl acetate $(50 \mathrm{~mL})$ and washed successively with $20 \% \mathrm{HCl}$ solution $(5 \times 50 \mathrm{~mL})$. The organic layer was concentrated under reduced pressure to give the $p$-DGA-benzoic acid (4) in quantitative yield. ${ }^{1} \mathrm{H}$ NMR: $\delta 0.84-$ $0.96\left(6 \mathrm{H}, \mathrm{m}, \mathrm{CH}_{3}\right), 1.21-1.38\left(20 \mathrm{H}, \mathrm{m}, \mathrm{CH}_{3}\left(\mathrm{CH}_{2}\right)_{5}\right), 1.45-1.62$ $\left(4 \mathrm{H}, \mathrm{m}, \mathrm{NCH}_{2} \mathrm{CH}_{2}\right), 2.10\left(2 \mathrm{H}\right.$, pentet, $\left.J=6.4 \mathrm{~Hz}, \mathrm{OCH}_{2} \mathrm{CH}_{2}\right)$, $3.09,3.31\left(2 \mathrm{H}, \mathrm{t}, J=7.5 \mathrm{~Hz}, \mathrm{NCH}_{2}\right), 3.54(2 \mathrm{H}, \mathrm{q}, J=6.4 \mathrm{~Hz}$, $\left.\mathrm{NHCH}_{2}\right), 4.11\left(2 \mathrm{H}, \mathrm{t}, J=6.4 \mathrm{~Hz}, \mathrm{OCH}_{2}\right), 4.12,4.27\left(2 \mathrm{H}, \mathrm{s}, \mathrm{OCH}_{2}\right)$, 6.93, $8.01(2 \mathrm{H}, \mathrm{d}, J=8.8 \mathrm{~Hz}, \mathrm{ArH}), 8.11-8.19(1 \mathrm{H}, \mathrm{m}, \mathrm{NH}) .{ }^{13} \mathrm{C}$ NMR: $\delta$ 14.2, 20.7, 22.6, 26.8, 27.5, 28.8, 29.1, 31.8, 36.2, 46.3, 46.9, 60.4, 65.8, 69.5, 71.7, 113.7, 122.1, 132.1, 163.13, 168.5, 170.4, 175.6. HRMS: calculated 535.3747 for $\mathrm{C}_{30} \mathrm{H}_{51} \mathrm{~N}_{2} \mathrm{O}_{6}$; found: 535.3769, $[\mathrm{M}+\mathrm{H}]^{+}$.

Synthesis of p-DGA-benzoyl chloride (5). To a solution of $p$-DGA benzoic acid (4) $(2.00 \mathrm{~g}, 3.7 \mathrm{mmol})$ in dichloromethane $(50 \mathrm{~mL})$ was added a solution of oxalyl chloride $(0.51 \mathrm{~g}, 4.0 \mathrm{mmol})$ in dichloromethane $(20 \mathrm{~mL})$ and a few drops of DMF as a catalyst. The resulting solution was refluxed overnight. The solvent was evaporated under reduced pressure to give $p$-DGA-benzoyl chloride (5) as an oil, which was directly used in the next step. ${ }^{1} \mathrm{H}$ NMR: $\delta$ 0.81-0.96 $\left(6 \mathrm{H}, \mathrm{m}, \mathrm{CH}_{3}\right), 1.16-1.39(20 \mathrm{H}, \mathrm{m}$, $\left.\mathrm{CH}_{3}\left(\mathrm{CH}_{2}\right)_{5}\right), 1.45-1.62\left(4 \mathrm{H}, \mathrm{m}, \mathrm{NCH}_{2} \mathrm{CH}_{2}\right), 2.13(2 \mathrm{H}$, pentet, $J=$ $\left.6.4 \mathrm{~Hz}, \mathrm{OCH}_{2} \mathrm{CH}_{2}\right), 3.09,3.30\left(2 \mathrm{H}, \mathrm{t}, J=7.5 \mathrm{~Hz}, \mathrm{NCH}_{2}\right), 3.55(2 \mathrm{H}$, $\left.\mathrm{q}, J=6.4 \mathrm{~Hz}, \mathrm{NHCH}_{2}\right), 4.17\left(2 \mathrm{H}, \mathrm{t}, J=6.4 \mathrm{~Hz}, \mathrm{OCH}_{2}\right), 4.17,4.28$ $\left(2 \mathrm{H}, \mathrm{s}, \mathrm{OCH}_{2}\right), 7.00,8.08(2 \mathrm{H}, \mathrm{d}, J=8.8 \mathrm{~Hz}, \mathrm{ArH}), 8.11-8.19(1 \mathrm{H}$, $\mathrm{m}, \mathrm{NH})$.

Synthesis of resin-I. To a suspension of amino-functionalized silica particles (6) (degree of functionalization $=0.07 \mathrm{mmol} \mathrm{g}^{-1}$ ) $(1.5 \mathrm{~g})$ in dichloromethane $(50 \mathrm{~mL})$ containing triethylamine was added $p$-DGA-benzoyl chloride (5) (1.61 g) in dichloromethane $(15 \mathrm{~mL})$ at $0{ }^{\circ} \mathrm{C}$. The reaction mixture was brought to room temperature and stirring was continued for 5 days. The reaction mixture was filtered, washed with dichloromethane, and the residue was dried under vacuum pump to get the DGA-functionalized silica particles (resin-I).

Synthesis of ethyl 3,5-bis(phthalimidopropoxy)benzoate (9). A mixture of commercially available ethyl 3,5-dihydroxybenzoate (7) $(2.50 \mathrm{~g}, 13.7 \mathrm{mmol}), \mathrm{N}$-(3-bromopropyl)phthalimide (8) (7.35 g, $27.4 \mathrm{mmol}), \mathrm{K}_{2} \mathrm{CO}_{3}(3.5 \mathrm{~g}, 25.3 \mathrm{mmol})$, and $\mathrm{KI}(2.00 \mathrm{~g})$ in acetonitrile $(100 \mathrm{~mL})$ was refluxed overnight. The acetonitrile was evaporated and the residue was dissolved in dichloromethane $(100 \mathrm{~mL})$. The resulting solution was washed with dil. 
$\mathrm{HCl}(3 \times 50 \mathrm{~mL})$ and water $(2 \times 100 \mathrm{~mL})$. The organic layer was dried over anhydrous $\mathrm{MgSO}_{4}$ and concentrated under reduced pressure and the residue was recrystallized with methanol to afford pure product (9) (4.65 g, 61\%) as a white solid. M.p. 107$109{ }^{\circ} \mathrm{C}$. Elem. anal. calculated: C, 66.90; H, 5.07; N, 5.03, found: C, 66.83; H, 5.22; N, 4.69\%. ${ }^{1} \mathrm{H}$ NMR: $\delta 1.36(3 \mathrm{H}, \mathrm{t}, J=7.2 \mathrm{~Hz}$, $\left.\mathrm{OCH}_{2} \mathrm{CH}_{3}\right), 2.17\left(4 \mathrm{H}\right.$, pentet, $\left.J=6.4 \mathrm{~Hz}, \mathrm{OCH}_{2} \mathrm{CH}_{2}\right), 3.90(4 \mathrm{H}, \mathrm{t}, J$ $\left.=6.4 \mathrm{~Hz}, \mathrm{NCH}_{2}\right), 4.00\left(4 \mathrm{H}, \mathrm{t}, J=6.4 \mathrm{~Hz}, \mathrm{NCH}_{2}\right), 4.32(4 \mathrm{H}, \mathrm{q}, J=$ $\left.7.2 \mathrm{~Hz}, \mathrm{C}(\mathrm{O}) \mathrm{OCH}_{2}\right), 6.39$ (1H, s, ArH), 7.05 (2H, s, ArH), 7.697.75 (4H, m, ArH, phthalimide), 7.80-7.95 (4H, m, ArH, phthalimide). ${ }^{13} \mathrm{C}$ NMR: $\delta$ 14.2, 28.2, 35.4, 60.9, 65.9, 106.0, 107.7, 123.3, 132.0, 133.9, 159.6, 166.2, 168.3.

Synthesis of ethyl 3,5-bis(aminopropoxy)benzoate (10). Hydrazine hydrate $(10 \mathrm{~mL}, 200 \mathrm{mmol})$ was added to a suspension of ester $9(2.00 \mathrm{~g}, 3.6 \mathrm{mmol})$ in a $6: 3$ mixture of ethanoldichloromethane $(90 \mathrm{~mL})$. The mixture was refluxed for $12 \mathrm{~h}$, cooled and then diluted with water $(100 \mathrm{~mL})$. The precipitate formed was filtered and subsequently extracted with dichloromethane $(4 \times 50 \mathrm{~mL})$. The organic layer was then dried $\left(\mathrm{MgSO}_{4}\right)$ and the solvent evaporated to give $\mathbf{1 0}$ as an oil in quantitative yield. ${ }^{1} \mathrm{H}$ NMR: $\delta 1.40\left(3 \mathrm{H}, \mathrm{t}, J=7.2 \mathrm{~Hz}, \mathrm{OCH}_{2} \mathrm{CH}_{3}\right), 1.95(2 \mathrm{H}$, pentet, $\left.J=6.4 \mathrm{~Hz}, \mathrm{OCH}_{2} \mathrm{CH}_{2}\right), 2.93\left(2 \mathrm{H}, \mathrm{t}, J=6.4 \mathrm{~Hz}, \mathrm{NCH}_{2}\right)$, $4.09\left(2 \mathrm{H}, \mathrm{t}, J=6.4 \mathrm{~Hz}, \mathrm{NCH}_{2}\right), 4.37(2 \mathrm{H}, \mathrm{q}, J=7.2 \mathrm{~Hz}, \mathrm{C}(\mathrm{O})$ $\left.\mathrm{OCH}_{2}\right), 6.66(1 \mathrm{H}, \mathrm{s}, \mathrm{ArH}), 7.19(2 \mathrm{H}, \mathrm{s}, \mathrm{ArH}) .{ }^{13} \mathrm{C}$ NMR: $\delta 14.2$, 28.3, 35.4, 60.8, 65.9, 106.1, 107.7, 123.2, 159.6, 166.1. HRMS: calculated 297.1814 for $\mathrm{C}_{15} \mathrm{H}_{25} \mathrm{~N}_{2} \mathrm{O}_{4}$; found: 297.1794, $[\mathrm{M}+\mathrm{H}]^{+}$.

Synthesis of ethyl 3,5-di-DGA-benzoate (11). It was prepared by a similar procedure as described for the synthesis of ester 3 starting from $N, N^{\prime}$-dioctyldiglycolamic acid (2) (5.00 g, 13.9 $\mathrm{mmol})$, diamine $10(2.07 \mathrm{~g}, 7.0 \mathrm{mmol})$, triethylamine $(1.51 \mathrm{~g}$, $15.0 \mathrm{mmol}$ ), DCC (3.09 g, $15.0 \mathrm{mmol}$ ), and HOBT (2.02 g, 15.0 $\mathrm{mmol})$ in chloroform $(200 \mathrm{~mL})$. The crude product was purified by column chromatography $\left(\mathrm{SiO}_{2}, \mathrm{CH}_{2} \mathrm{Cl}_{2}-\mathrm{MeOH}=96: 4\right)$ to get ester $11(8.31 \mathrm{~g}, 61 \%)$ as an oil. ${ }^{1} \mathrm{H}$ NMR: $\delta 0.84-0.95(12 \mathrm{H}, \mathrm{m}$, $\left.\mathrm{CH}_{3}\right), 1.19-1.36\left(40 \mathrm{H}, \mathrm{m}, \mathrm{CH}_{3}\left(\mathrm{CH}_{2}\right)_{5}\right), 1.40(6 \mathrm{H}, \mathrm{t}, J=7.2 \mathrm{~Hz}$, $\mathrm{OCH}_{2} \mathrm{CH}_{3}$ ), 1.46-1.61 (8H, m, $\mathrm{NCH}_{2} \mathrm{CH}_{2}$ ), 2.07 (4H, pentet, $J=$ $\left.6.4 \mathrm{~Hz}, \mathrm{OCH}_{2} \mathrm{CH}_{2}\right), 3.10,3.30\left(4 \mathrm{H}, \mathrm{t}, J=7.5 \mathrm{~Hz}, \mathrm{NCH}_{2}\right), 3.52(4 \mathrm{H}$, $\left.\mathrm{q}, J=6.4 \mathrm{~Hz}, \mathrm{NHCH}_{2}\right), 4.07\left(4 \mathrm{H}, \mathrm{t}, J=6.4 \mathrm{~Hz}, \mathrm{OCH}_{2}\right), 4.10,4.27$ $\left(4 \mathrm{H}, \mathrm{s}, \mathrm{OCH}_{2}\right), 4.36\left(4 \mathrm{H}, \mathrm{q}, J=7.2 \mathrm{~Hz}, \mathrm{C}(\mathrm{O}) \mathrm{OCH}_{2}\right), 6.67(1 \mathrm{H}, \mathrm{s}$, $\mathrm{ArH}), 7.18(2 \mathrm{H}, \mathrm{s}, \mathrm{ArH}), 8.00(1 \mathrm{H}, \mathrm{br} \mathrm{s}, \mathrm{NH}) .{ }^{13} \mathrm{C}$ NMR: $\delta 14.4$, 22.7, 26.8, 27.5, 28.7, 29.3, 31.7, 36.4, 46.3 , 46.9, 60.4, 66.0, 69.5, 71.7, 108.2, 131.7, 159.7, 168.4, 169.0, 170.0. HRMS: calculated 975.7361 for $\mathrm{C}_{55} \mathrm{H}_{99} \mathrm{~N}_{4} \mathrm{O}_{10}$; found: $975.7415,[\mathrm{M}+\mathrm{H}]^{+}$.

Synthesis of 3,5-di-DGA-benzoic acid (12). It was synthesized in a similar way as described for the synthesis of $\mathbf{4}$ in quantitative yield. ${ }^{1} \mathrm{H}$ NMR: $\delta$ 0.83-0.95 $\left(12 \mathrm{H}, \mathrm{m}, \mathrm{CH}_{3}\right), 1.19-1.39(40 \mathrm{H}, \mathrm{m}$, $\left.\mathrm{CH}_{3}\left(\mathrm{CH}_{2}\right)_{5}\right), 1.44-1.63$ (8H, m, $\mathrm{NCH}_{2} \mathrm{CH}_{2}$ ), 2.09 (4H, pentet, $J=$ $\left.6.4 \mathrm{~Hz}, \mathrm{OCH}_{2} \mathrm{CH}_{2}\right), 3.10,3.31\left(2 \mathrm{H}, \mathrm{t}, J=7.5 \mathrm{~Hz}, \mathrm{NCH}_{2}\right), 3.54(2 \mathrm{H}$, $\left.\mathrm{q}, J=6.4 \mathrm{~Hz}, \mathrm{NHCH}_{2}\right), 4.04\left(2 \mathrm{H}, \mathrm{t}, J=6.4 \mathrm{~Hz}, \mathrm{OCH}_{2}\right), 4.12,4.27$ $\left(4 \mathrm{H}, \mathrm{s}, \mathrm{OCH}_{2}\right), 6.65(1 \mathrm{H}, \mathrm{s}, \mathrm{ArH}), 7.19(2 \mathrm{H}, \mathrm{s}, \mathrm{ArH}), 8.05-8.14(1 \mathrm{H}$, $\mathrm{m}, \mathrm{NH}) .14 .4,22.7,26.8,27.5,28.2,28.7,29.3,31.7,36.4,46.3$, 46.9, 60.4, 66.0, 69.5, 71.7, 108.2, 131.7, 159.7, 168.4, 169.0, 170.0. HRMS: calculated 947.7048 for $\mathrm{C}_{53} \mathrm{H}_{95} \mathrm{~N}_{4} \mathrm{O}_{10}$; found: 947.7125, $[\mathrm{M}+\mathrm{H}]^{+}$.

3,5-Di-DGA-benzoyl chloride (13). It was synthesized in the same way as described for the preparation of $\mathbf{5}$ in quantitative yield and was directly used. ${ }^{1} \mathrm{H}$ NMR: $\delta$ 0.83-0.95 $\left(12 \mathrm{H}, \mathrm{m}, \mathrm{CH}_{3}\right)$,
1.19-1.38 (40H, m, $\left.\mathrm{CH}_{3}\left(\mathrm{CH}_{2}\right)_{5}\right), 1.46-1.61\left(8 \mathrm{H}, \mathrm{m}, \mathrm{NCH}_{2} \mathrm{CH}_{2}\right)$, $2.09\left(4 \mathrm{H}\right.$, pentet, $\left.J=6.4 \mathrm{~Hz}, \mathrm{OCH}_{2} \mathrm{CH}_{2}\right), 3.10,3.31(2 \mathrm{H}, \mathrm{t}, J=7.5$ $\left.\mathrm{Hz}, \mathrm{NCH}_{2}\right), 3.54\left(2 \mathrm{H}, \mathrm{q}, J=6.4 \mathrm{~Hz}, \mathrm{NHCH}_{2}\right), 4.09(2 \mathrm{H}, \mathrm{t}, J=6.4$ $\left.\mathrm{Hz}, \mathrm{OCH}_{2}\right), 4.18,4.30\left(4 \mathrm{H}, \mathrm{s}, \mathrm{OCH}_{2}\right), 6.79(1 \mathrm{H}, \mathrm{s}, \mathrm{ArH}), 7.23(2 \mathrm{H}$, s, ArH), 8.41-8.55 (1H, m, NH).

Synthesis of resin-II. Resin-II was prepared in an analogous way as described for resin-I starting from 3,5-di-DGA-benzoyl chloride (13) and amino-terminated silica particles (6).

2.1.2. Radiotracers. The actinide radiotracers were taken from laboratory stock solutions and were used after purification from the daughter products. On the other hand, ${ }^{152,154} \mathrm{Eu},{ }^{137} \mathrm{Cs}$, and ${ }^{85,89} \mathrm{Sr}$ were obtained from the Board of Radiation and Isotope Technology (BRIT), Mumbai. ${ }^{241}$ Am was purified by the procedure given elsewhere. ${ }^{21}{ }^{233} \mathrm{U}$ tracer was purified from its daughter products by an anion exchange method described elsewhere ${ }^{22}$ and its purity was confirmed by $\alpha$-spectrometry. $\mathrm{Pu}$ (principally ${ }^{239} \mathrm{Pu}$ ) was purified from ${ }^{241} \mathrm{Am}$ by an anion exchange method from $7 \mathrm{M} \mathrm{HNO}_{3}$ feeds and its radiochemical purity was ascertained by gamma-ray spectrometry for the absence of ${ }^{241} \mathrm{Am}^{21}$

The conversion of $\mathrm{Pu}$ to its +4 oxidation state was carried out using a standard procedure using drop wise addition of a sodium nitrite solution $(0.05 \mathrm{M})$ into a solution of $\mathrm{Pu}$ in $1 \mathrm{M}$ $\mathrm{HNO}_{3}$ followed by the extraction of $\mathrm{Pu}^{4+}$ by $0.5 \mathrm{M}$ TTA in xylene. The extracted $\mathrm{Pu}^{4+}$ was subsequently stripped with $8 \mathrm{M} \mathrm{HNO}_{3}$, which was then used as stock for $\mathrm{Pu}^{4+}$. Further, during the studies, the plutonium valency in the aqueous phase was adjusted and maintained in the tetravalent state by the addition of $1 \times 10^{-3} \mathrm{M} \mathrm{NH}_{4} \mathrm{VO}_{3}$ as the holding oxidant.

Assaying of ${ }^{241} \mathrm{Am},{ }^{137} \mathrm{Cs},{ }^{85,89} \mathrm{Sr}$, and ${ }^{152,154} \mathrm{Eu}$ was done by gamma counting using a $\mathrm{NaI}(\mathrm{Tl})$ scintillation counter (Para Electronics, India) interphased to a multi-channel analyzer (ECIL, India), while nuclides such as ${ }^{239} \mathrm{Pu}$ and ${ }^{233} \mathrm{U}$ were assayed by a liquid scintillation counting system (Hidex, Finland) using an Ultima Gold scintillator cocktail (Sisco Research Laboratory, Mumbai).

\subsection{Methods}

2.2.1. Instrumental methods. The SEM pictures of the resin beads were obtained using a Stereoscan 100 Cambridge model operating at $15 / 25 \mathrm{kV}$ with a magnification of $500 \times$ at a working distance of $15 \mathrm{~mm}$ at a tilt angle of $45^{\circ}$. Since the resin materials are non-conducting, a $15 \mathrm{~nm}$ coating of gold was given to the samples using a Balzer's coating unit model CEA 30. Thermogravimetric analyses were performed using a Netzsch Thermobalance (Model: STA 409 PC Luxx), at a heating rate of $10{ }^{\circ} \mathrm{C} \mathrm{min}^{-1}$, in air. Surface area analysis of the resins was carried out using equipment supplied by Thermo Scientific.

2.2.2. Distribution studies. The sorption of metal ions onto the resin materials was determined by equilibrating a known volume of an aqueous solution (usually, $1 \mathrm{~mL}$ ) containing the required radiotracer at a given acidity with a known quantity of resin ( $20-50 \mathrm{mg})$ in leak tight Pyrex glass tubes. The tubes were agitated in a thermostated water bath maintained at $25 \pm$ $0.1{ }^{\circ} \mathrm{C}$ for $1 \mathrm{~h}$, which was optimized from the sorption kinetics studies (vide infra). Subsequently, the tubes were centrifuged to 
clearly settle the resin materials and suitable aliquots (usually $100 \mu \mathrm{L}$ ) of the aqueous phase were removed for the assaying of the metal ions as mentioned above. The distribution coefficients $\left(K_{\mathrm{d}}\right)$ were calculated from the counts in the aqueous phase prior to the uptake by the resin material $\left(C_{\mathrm{o}}\right)$ and those obtained after equilibration $\left(C_{\text {eq }}\right)$ as per the following formula:

$$
K_{\mathrm{d}}=\left[\left(C_{\mathrm{o}}-C_{\mathrm{eq}}\right) / C\right] V / W\left(\mathrm{~mL} \mathrm{~g} \mathrm{~g}^{-1}\right)
$$

where $V$ is the volume of the aqueous phase used $(\mathrm{mL})$, and $W$ is the weight of the resin material employed $(\mathrm{g})$. All experiments were carried out in duplicate and the reproducibility of the results was within $\pm 5 \%$.

\section{Results and discussion}

\subsection{Synthesis of the resins}

Resins-1 and -II were prepared as summarized in Schemes 1 and 2 , respectively. $N, N^{\prime}$-Dioctyldiglycolamic acid (1) and ethyl 4-aminopropoxybenzoate (2) were reacted under peptide coupling conditions to give ethyl $p$-DGA-benzoate 3 in $79 \%$ yield. Subsequent hydrolysis of the ester moiety in 3 afforded the corresponding $p$-DGA-benzoic acid (4) in quantitative yield, which was reacted with oxalyl chloride to give $p$-DGA-benzoyl chloride (5). A suspension of amino-functionalized silica particles (6) in dichloromethane was reacted with acid chloride $\mathbf{5}$ to give resin-I.

Ethyl dihydroxybenzoate (7) was dialkylated with two equiv. of $\mathrm{N}$-(3-bromopropyl)phthalimide (8) in the presence of potassium iodide and potassium carbonate as a base to give ethyl 3,5bis(phthalimidopropoxy)benzoate (9) in 61\% yield. Subsequent treatment with hydrazine afforded ethyl 3,5-bis(aminopropoxy)benzoate (10) in quantitative yield. In a similar way as described above resin-II was prepared.

\subsection{Characterization of the resins}

Some of the physical parameters of the resins are listed in Table 1. In the IR spectra the resins-I and -II showed broad absorption bands at $1650-1600 \mathrm{~cm}^{-1}$ corresponding to the amide $\mathrm{C}=\mathrm{O}$ groups. Solid state ${ }^{13} \mathrm{C}$ NMR spectroscopy showed peaks at 11.8, 23.0, 24.7, 29.3, 31.6, 34.1, and 44.9 ppm for resin-I and at 11.73, 23.1, 24.81, 29.4, 31.7, 34.0, 45.0, 49.5, and 99.9 for resin-II, clearly indicating the functionalization of the silica particles. The resins were characterized by various methods such as thermal analysis (TG-DTA), surface area by BET, and surface morphology by SEM. The thermal analysis data are presented in Fig. 2 which show about $34 \%$ and $58 \%$ weight loss with the resins-I and -II, respectively, which closely correspond to the DGA groups appended onto the silica particles. The average particle size of the grafted resins was determined by SEM as 80 and 70 microns for resins-I and -II, respectively. The SEM micrographs of the resins at $200 \times$ and $1000 \times$ magnifications are shown in Fig. 3. The resin particles were nearly spherical in most cases, which results in a very high surface area. BET analysis gave 180 and $429 \mathrm{~m}^{2} \mathrm{~g}^{-1}$ as the surface areas of the resins-I and -II, respectively. Further magnification to $10000 \times$ (Fig. 3) indicated a layered surface morphology of the resins, which was more prominent in case of resin-II.

\subsection{Sorption of $\mathrm{Am}(\mathrm{III})$ from $\mathrm{HNO}_{3}$ solutions}

High level radioactive waste contains about $3 \mathrm{M} \mathrm{HNO}_{3}$ apart from various actinides, fission product elements and structural elements. In view of this, the Am(III) uptake behavior of the resin materials was investigated from a $3 \mathrm{M} \mathrm{HNO}_{3}$ solution. Distribution coefficients of 1850 and 3050 were obtained for resin-I and resin-II, respectively, from triplicate measurements. The metal ion sorption kinetics was monitored in terms of fractional attainment of the equilibrium expressed as follows:

$$
F=\left[\mathrm{M}^{\mathrm{R}}\right]_{t} /\left[\mathrm{M}^{\mathrm{R}}\right]_{\mathrm{eq}}
$$

where $\left[\mathrm{M}^{\mathrm{R}}\right]_{t}$ and $\left[\mathrm{M}^{\mathrm{R}}\right]_{\mathrm{eq}}$ are the metal ion concentrations in the solid phase at time ' $t$ ' and at equilibrium, respectively. Fig. 4 shows the sorption kinetics data of Am(III) on the grafted resins. The sorption of Am(III) onto resin-I was slow and the plateau<smiles>CCOC(=O)c1ccc(OCCCN)cc1</smiles>

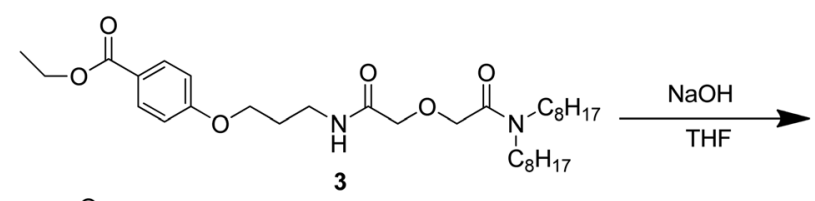
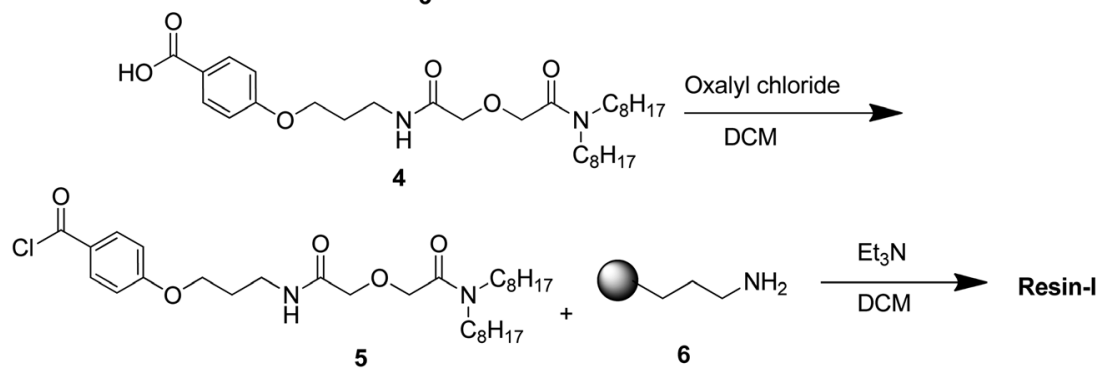

Scheme 1 Synthesis of resin-I. 


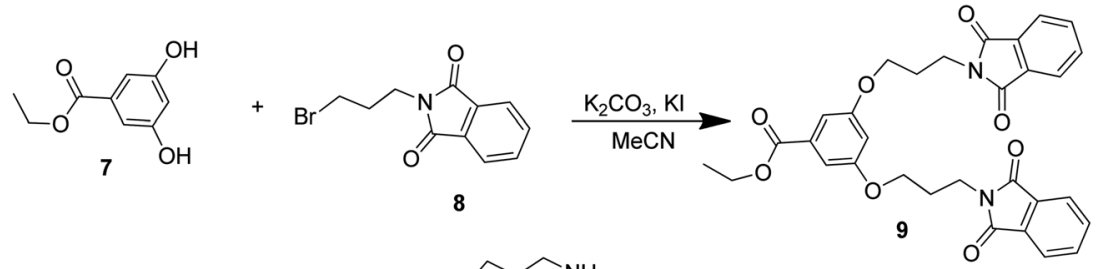<smiles>CCN(CC)C(=O)COCC(=O)NCCCO</smiles>

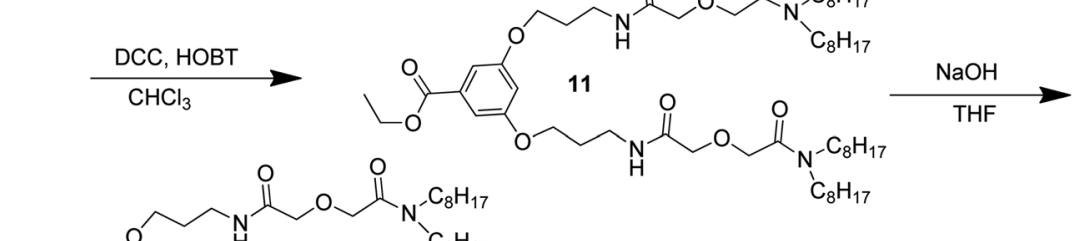

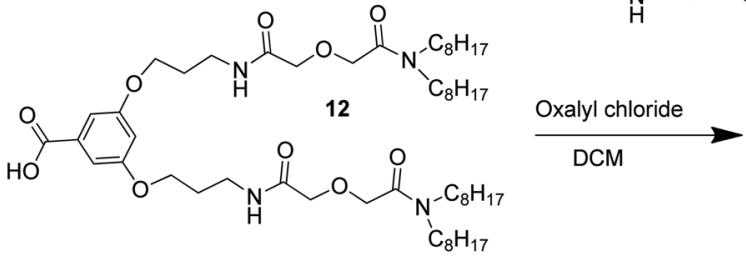<smiles>CCCCN(CC)C(=O)COCC(=O)NCCCOc1cc(OCCCN)cc(C(=O)NCCCOc2ccccc2)c1</smiles>

Scheme 2 Synthesis of resin-II.

values were approached after 20 minutes of equilibration, however, in case of resin-II, equilibrium was reached in 10 minutes.

The diglycolamide extractants TODGA and T2EHDGA are reported to extract metal ions by a solvation mechanism, commonly observed with neutral donor extractants. ${ }^{23}$ It has a

Table 1 Resin parameters for pre-concentration of Am(III)

\begin{tabular}{|c|c|c|}
\hline Parameter & Resin-I & Resin-II \\
\hline Resin type & $\begin{array}{l}\text { Silica particles } \\
\text { appended with } \\
\text { one DGA moiety }\end{array}$ & $\begin{array}{l}\text { Silica particles appended } \\
\text { with two DGA moieties }\end{array}$ \\
\hline Particle size $(\mu \mathrm{m})$ & $70 \pm 20$ & $80 \pm 20$ \\
\hline Surface area $\left(\mathrm{m}^{2} \mathrm{~g}^{-1}\right)$ & 180 & 429 \\
\hline Density $\left(\mathrm{g} \mathrm{mL}^{-1}\right)$ & 0.982 & 0.973 \\
\hline Color & Pale yellow & Pale yellow \\
\hline $\begin{array}{l}\text { Affinity for water or } \\
\text { acid solution }\end{array}$ & Good & Good \\
\hline \multicolumn{3}{|l|}{ Column characteristics } \\
\hline Bed volume & - & $0.82 \mathrm{~cm}^{3}$ \\
\hline Bed density & - & $0.49 \mathrm{~g} \mathrm{~cm}^{-3}$ \\
\hline Flow rate & - & 4 drops per min \\
\hline Feed solution & - & $3 \mathrm{M} \mathrm{HNO}_{3}$ \\
\hline Eluent & - & $0.01 \mathrm{M}$ EDTA \\
\hline
\end{tabular}

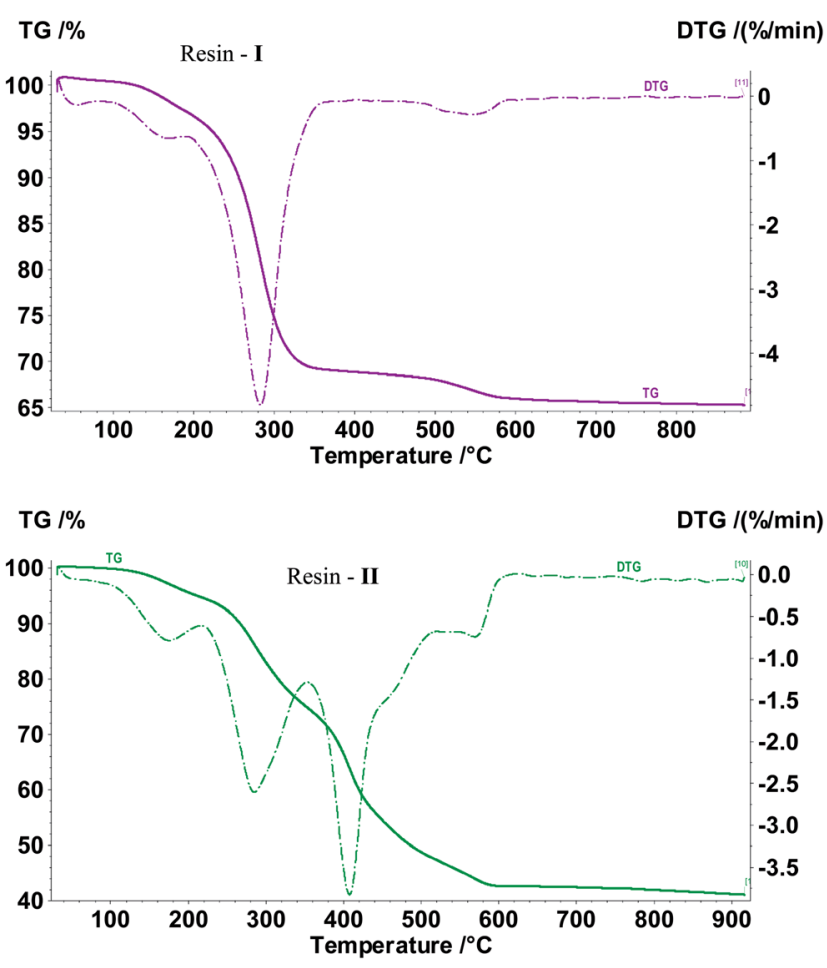

Fig. 2 Thermogravimetric analysis of the DGA-grafted resins. 


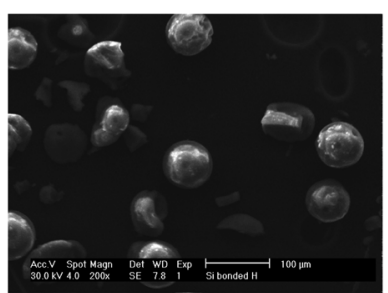

(a) $200 \mathrm{X}$

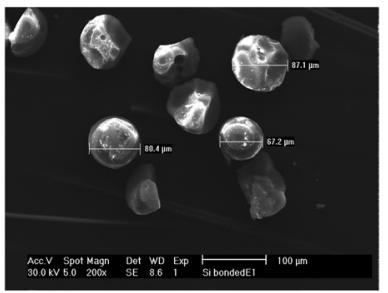

(a) $200 \mathrm{X}$

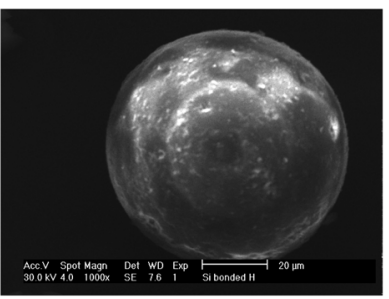

(b) $1000 \mathrm{X}$

Resin-I

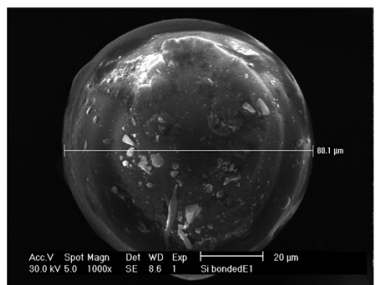

(b) $1000 \mathrm{X}$

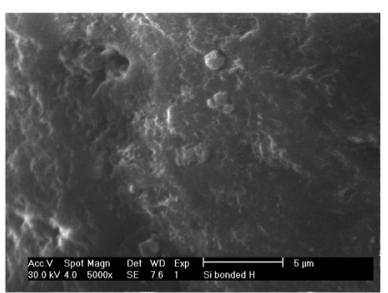

(c) $10000 \mathrm{X}$

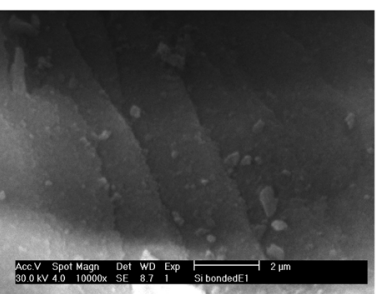

(c) $10000 \mathrm{X}$

\section{Resin-II}

Fig. 3 SEM micrographs of the DGA-functionalized resins.

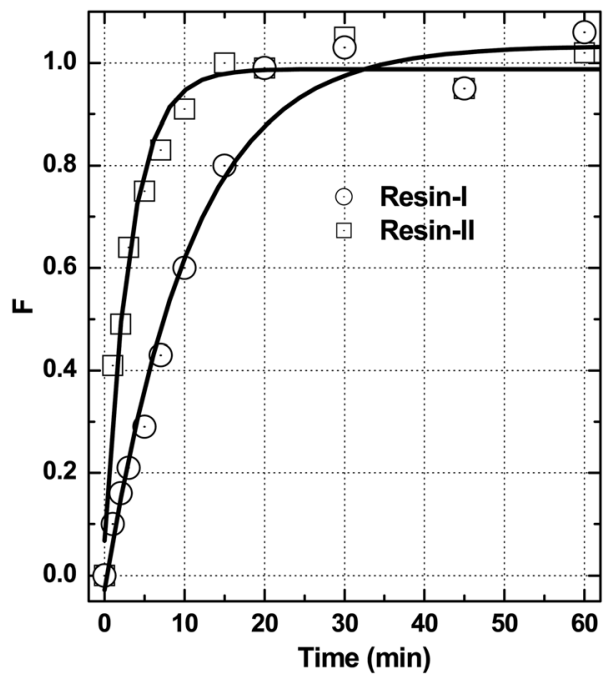

Fig. 4 Fractional sorption of Am(III) with time on the DGA-grafted resins; aqueous phase: $3 \mathrm{M} \mathrm{HNO}_{3}$; temperature: $25^{\circ} \mathrm{C}$.

signature of increased metal ion extraction with increasing nitric acid concentration up to a certain acidity beyond which a plateau is observed. ${ }^{9,10}$ A similar trend was also seen in solid phase extraction studies involving extraction chromatographic resin materials containing diglycolamide extractants as the stationary phase. ${ }^{15}$ On the other hand, studies on the effect of the $\mathrm{HNO}_{3}$ concentration on the sorption of Am(III) by the DGAgrafted resins-I and -II (Fig. 5) showed a rather unusual behavior of an increase in the uptake of the metal ion with increasing acidity up to $6 \mathrm{M} \mathrm{HNO}_{3}$. Horwitz et al. ${ }^{\mathbf{1 4}}$ have observed a similar trend with both TODGA-as well as T2EHDGA-based extraction chromatographic resin materials. At any given acidity, the distribution coefficient of Am(III) by resin-II was higher than

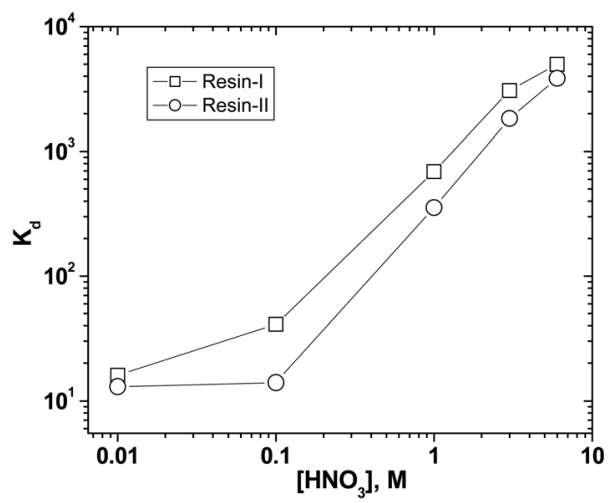

Fig. 5 Distribution coefficients of $A m\left(\right.$ III) as a function of the $\mathrm{HNO}_{3}$ concentration by the DGA-grafted resins; temperature: $25^{\circ} \mathrm{C}$.

that of resin-I. This feature can be ascribed to the higher diglycolamide density present at resin-II.

The batch uptake capacity of the resins was determined by equilibrating about $100 \mathrm{mg}$ of the resin materials with a feed solution containing about $100 \mathrm{mg} \mathrm{L}{ }^{-1} \mathrm{Eu}(\mathrm{III})$ in $3 \mathrm{M} \mathrm{HNO}_{3}$ at $25 \pm 0.1^{\circ} \mathrm{C}$ for $24 \mathrm{~h}$ to give values of 11 and $14 \mathrm{mg} \mathrm{g}^{-1}$ for resinsI and -II, respectively. Though TODGA-impregnated extraction chromatographic resin material has higher metal ion uptake efficiency in terms of larger $K_{\mathrm{d}}$ values (vide infra), the capacity was reported to be lower, namely $10 \mathrm{mg} \mathrm{g}^{-1} \cdot{ }^{15}$

\subsection{Uptake of other actinide and fission product ions}

Radioactive wastes usually contain a host of actinide and fission product ions the most important of those being Am(III), U(VI), $\mathrm{Pu}(\mathrm{IV}), \mathrm{Sr}(\mathrm{II})$, and $\mathrm{Cs}(\mathrm{I})$. In addition, some of the rare earth elements are also likely to be present. ${ }^{2-5}$ In the present study, 
the uptake behavior of these metal ions along with $\mathrm{Eu}(\mathrm{III})$ (representative of the rare earth elements) was studied from $3 \mathrm{M}$ $\mathrm{HNO}_{3}$. The metal ion uptake data show the following trend for resin-I: $\mathrm{Eu}(\mathrm{III})>\mathrm{Pu}(\mathrm{IV}) \geq \mathrm{Am}(\mathrm{III}) \gg \mathrm{U}(\mathrm{VI})>\mathrm{Cs}(\mathrm{I})>\mathrm{Sr}(\mathrm{II})$. The $K_{\mathrm{d}}$ values with resin-II are about 1.5-2 times larger, except for Cs(I), which is expected on the basis of their ligating group density. The $K_{\mathrm{d}}$ values for Eu(III) were compared with those reported in previous studies. Extraction chromatographic materials made by Anasari et al. ${ }^{15}$ and Horwitz et al. ${ }^{14}$ exhibited a significantly higher uptake of $\mathrm{Eu}(\mathrm{III})$ from $3 \mathrm{M} \mathrm{HNO}_{3}$ with $K_{\mathrm{d}}$ values in the range of $\sim 10^{4}$ as compared to values of 2705 and 5650 obtained with resins-I and -II, respectively. This could be ascribed to several factors which include, higher ligand loading in the extraction chromatographic resins, reported earlier, favourable diffusion coefficient values with the extraction chromatographic resins due to the presence of a liquid phase rather than the entirely solid phase in the present resins which would have lower diffusion coefficients. Zhang et al. reported a $K_{\mathrm{d}}$ value for $\mathrm{La}$ (III) of $\sim 1000$, while $\mathrm{Nd}$ (III) yielded $K_{\mathrm{d}}$ values in the excess of $>10^{4}$ using a feed consisting of $0.1 \mathrm{M} \mathrm{HNO}_{3}$ and $3 \mathrm{M}$ nitrate and 0.05 M DTPA, which, however, operates in an entirely different mechanism. $^{24}$

The selectivity coefficients, defined as the ratio of the $K_{\mathrm{d}}$ values of Am(III) and the metal ion of interest, were also calculated and are listed in Table 2. These data suggest that the separation of $\mathrm{Am}$ (III) with respect to Eu(III) and Pu(IV) is not very encouraging, while that with respect to $\mathrm{U}$ is reasonably high. The very large selectivity coefficients with respect to $\operatorname{Sr}$ (II) and $\mathrm{Cs}(\mathrm{I})$ indicate that ${ }^{137} \mathrm{Cs}$ and ${ }^{90} \mathrm{Sr}$ can be very easily decontaminated from the sorbed Am(III). We have previously prepared a malonamide-grafted resin, which showed about 30 and 5000 times lower selectivity coefficients with respect to $\mathrm{Pu}(\mathrm{Iv})$ and

Table 2 Distribution coefficients of metal ions by DGA-functionalized resins-I and -II obtained using $3 \mathrm{M} \mathrm{HNO}_{3}$

\begin{tabular}{|c|c|c|c|c|}
\hline \multirow[b]{2}{*}{ Metal ions } & \multicolumn{2}{|c|}{$K_{\mathrm{d}}$ at $3 \mathrm{M} \mathrm{HNO}_{3}$} & \multicolumn{2}{|c|}{$\begin{array}{l}\text { Selectivity } \\
\text { coefficient }\left(K_{\mathrm{d}, \mathrm{Am}} / K_{\mathrm{d}, \mathrm{M}}\right)\end{array}$} \\
\hline & Resin-I & Resin-II & Resin-I & Resin-II \\
\hline Am(III) & 1850 & 3050 & - & - \\
\hline $\operatorname{Eu}(\mathrm{III})$ & 2705 & 5650 & 0.68 & 0.54 \\
\hline $\mathrm{Pu}(\mathrm{Iv})$ & 2150 & 3150 & 0.86 & 0.97 \\
\hline $\mathrm{Pu}(\mathrm{vI})$ & 15.0 & 23.0 & 123 & 133 \\
\hline $\mathrm{U}(\mathrm{vI})$ & 5.7 & 11.1 & 324 & 276 \\
\hline $\operatorname{Sr}($ II) & 0.33 & 0.75 & 5606 & 4067 \\
\hline $\operatorname{Cs}(\mathrm{I})$ & 0.67 & 0.68 & 2762 & 4485 \\
\hline
\end{tabular}

Table 3 Pre-concentration of metal ions by resin-II column; feed: $1 \mathrm{~L}$ $3 \mathrm{M} \mathrm{HNO}_{3}$ solution containing ${ }^{241} \mathrm{Am}$; Eluent: 0.01 EDTA

\begin{tabular}{lllll}
\hline $\begin{array}{l}\text { Metal } \\
\text { ions }\end{array}$ & $\begin{array}{l}\text { Conc. in } \\
\text { loading solution } \\
\left.(\mathrm{Bq} \mathrm{mL})^{-1}\right)\end{array}$ & $\begin{array}{l}\text { Amount }_{\text {eluted }^{a}} \\
(\mathrm{~Bq})\end{array}$ & $\begin{array}{l}\text { Percentage } \\
\text { Recovery }\end{array}$ & $\begin{array}{l}\text { Pre-concentration } \\
\text { factor }\end{array}$ \\
\hline Am(III) & 64.16 & 66615 & 103.83 & $>100$ \\
${ }^{a}$ As determined from $10 \mathrm{~mL}$ of the eluted fraction.
\end{tabular}

$\mathrm{U}(\mathrm{vI})$, respectively. ${ }^{25}$ It is interesting to note that the resins do not hold U(VI), Sr(II), and Cs(I), while metal ions such as Am(III), $\mathrm{Eu}(\mathrm{III})$, and $\mathrm{Pu}(\mathrm{IV})$ are effectively sorbed, suggesting that separation of trivalent lanthanides and actinides from $\mathrm{U}, \mathrm{Pu}, \mathrm{Sr}$, and $\mathrm{Cs}$ is possible by selectively oxidizing $\mathrm{Pu}$ to its hexavalent state.

\subsection{Analytical application}

One of the prerequisites of metal ion determination in dilute solutions is the pre-concentration of the trace metal ions in the feeds. In order to achieve pre-concentration of ${ }^{241} \mathrm{Am}$ present in dilute waste solutions, a column containing resin-II was used. The column parameters are summarized in Table 1. In an experiment carried out to evaluate the pre-concentration ability of this resin, a $1 \mathrm{~L}$ solution containing trace amounts of ${ }^{241} \mathrm{Am}$ (64.16 $\mathrm{Bq} \mathrm{mL}^{-1}$ ) at $3 \mathrm{M} \mathrm{HNO}_{3}$ was passed through the column at a flow rate of $10 \mathrm{~mL} \mathrm{~h}^{-1}$. During the loading step, no breakthrough was observed for ${ }^{241} \mathrm{Am}$, which was monitored by counting the effluents intermittently using a $\mathrm{NaI}(\mathrm{Tl})$ detector. After passing the entire lot of the solution, the elution was performed with $0.01 \mathrm{M}$ EDTA (at $\mathrm{pH} 2.0$ ); the results of the pre-concentration are summarized in Table 3. Quantitative recovery of ${ }^{241} \mathrm{Am}$ was possible with about $10 \mathrm{~mL}$ of the eluting solution, giving a preconcentration factor of $>100$. This is significantly better than the pre-concentration factor of about 40 obtained with the malonamide-grafted resin for the pre-concentration of $\mathrm{U}^{26}$

\section{Conclusions}

The newly prepared diglycolamide-grafted resins-I and -II showed an interesting sorption behavior of actinide ions from 3 $\mathrm{M}$ nitric acid solutions, the uptake and kinetics being dependent on the amount of DGA units present. The resins showed relatively lower extraction efficiency than the previously reported TODGA-based extraction chromatographic resins. ${ }^{\mathbf{1 4 , 1 5}}$ However, the metal ion uptake capacities were comparable and in view of the possibility of longer reusability the grafted resins may find application. The resins showed a better analytical performance in terms of the pre-concentration factor compared to the analogous malonamide-grafted resins. ${ }^{26}$

\section{Acknowledgements}

The authors (P. K. M. and S. A. A.) are thankful to Dr A. Goswami, Head Radiochemistry Division, for his constant encouragement and keen interest.

\section{References}

1 M. Piml, J. Radioanal. Nucl. Chem., 1995, 194, 311-318.

2 G. R. Choppin and A. Morgensten, J. Radioanal. Nucl. Chem., 2000, 243, 45-51.

3 P. A. Baisden and G. R. Choppin, Nuclear waste management and the nuclear fuel cycle, in Radiochemistry and Nuclear Chemistry, ed. S. Nagyl, Encyclopedia of Life Support Systems (EOLSS), Eolss Publishers, Oxford, UK, 2007. 
4 C. Apostolidis, R. D. Meester, L. Koch, R. Molinet, J. Liang and Y. Zhu, The extraction of actinides and other constituents from highly active waste (HAW) by trialkylphosphine oxide (TRPO), in New Separation Chemistry Techniques for Radioactive Waste and Other Specific Applications, ed. L. Cecille, M. Casarci and L. Pietrelli, Elsevier Applied Science, London and New York, 1991.

5 F. W. Lewis, M. J. Hudson and L. M. Harwood, Synlett, 2011, 2609-2632.

6 H. H. Dam, D. N. Reinhoudt and W. Verboom, Chem. Soc. Rev., 2007, 36, 367-377.

7 Z. Kolarik, Chem. Rev., 2008, 108, 4208-4252.

8 J. N. Mathur, M. S. Murali and K. L. Nash, Solvent Extr. Ion Exch., 2001, 19, 357-390.

9 S. A. Ansari, P. N. Pathak, P. K. Mohapatra and V. K. Manchanda, Sep. Purif. Rev., 2011, 40, 43-76.

10 R. B. Gujar, S. A. Ansari, M. S. Murali, P. K. Mohapatra and V. K. Manchanda, J. Radioanal. Nucl. Chem., 2010, 284, 377-385.

11 S. A. Ansari, P. N. Pathak, P. K. Mohapatra and V. K. Manchanda, Chem. Rev., 2002, 112, 1751-1772.

12 S. Maischak and J. Fachinger, Solid-phase extraction for the separation of actinides from radioactive waste. WM'01 Conference, Tucson, AZ, February 25-March 1, 2001.

13 M. Yamaura and H. T. Matsuda, J. Radioanal. Nucl. Chem., 1997, 224, 83-87.

14 E. P. Horwitz, D. R. McAlister, A. H. Bond and R. E. Barrans, Solvent Extr. Ion Exch., 2005, 23, 319-344.
15 S. A. Anasari, P. N. Pathak, M. Husain, A. K. Prasad, V. S. Parmar and V. K. Manchanda, Talanta, 2006, 68, 1273-1280.

16 H. Hoshi, Y. Z. Wei, M. Kumagai, T. Asakura and Y. Morita, J. Alloys Compd., 2004, 374, 451-455.

17 A. Zhang, Y. Z. Wei, H. Hoshi and M. Kumagai, Solvent Extr. Ion Exch., 2005, 23, 231-247.

18 A. Zhang, E. Kuraoka and M. Kumagai, Sep. Purif. Technol., 2006, 50, 35-44.

19 W. Lever Jr, L. N. Bell, C. Hyman, H. M. McGuire and R. Ferone, J. Med. Chem., 1986, 29, 665-670.

20 N. Djedovic, R. Ferdani, E. Harder, J. Pajewska, R. Pajewski, M. E. Weber, P. H. Schlesinger and G. W. Gokel, New J. Chem., 2005, 29, 291-305.

21 P. K. Mohapatra, Ph.D. thesis, University of Bombay, 1993.

22 S. S. Rattan, A. V. R. Reddy, V. S. Mallapurkar, R. J. Singh and S. A. Prakash, J. Radioanal. Chem., 1981, 67, 95-99.

23 V. K. Manchanda, P. N. Pathak and P. K. Mohapatra, New developments in thorium, uranium and plutonium extraction, in Ion Exchange and Solvent Extraction: A Series of Advances, 2009, ch. 2, vol. 19, pp. 65-118.

24 A. Zhang, E. Kuraoka and M. Kumagai, Eur. Polym. J., 2007, 43, 529-539.

25 S. A. Ansari, P. K. Mohapatra and V. K. Manchanda, Talanta, 2007, 73, 878-885.

26 S. A. Ansari, P. K. Mohapatra and V. K. Manchanda, J. Hazard. Mater., 2009, 161, 1323-1329. 